\title{
Evaluation of the Hypoglycemic Potentials and Glycemic Index of Ready-to-eat Breakfast Products Using Animal Bioassay
}

\author{
Onuh F. A.", Mbaeyi-Nwaoha I. E., Ani J.C. \\ Department of Food Science and Technology, University of Nigeria, Nsukka \\ *Corresponding author: ifeoma.mbaeyi-nwaoha@unn.edu.ng
}

Received April 17, 2019; Revised May 28, 2019; Accepted July 01, 2019

\begin{abstract}
There is need for dietary diversification which involves the use of commonly available cereals, legumes and other nutritious crops to meet nutritional needs of diabetic patients. Dietary diversification could be used to ameliorate micronutrient deficiencies by modifying the diet to include a greater diversity of nutrient - rich foods. The major aim of this study was to produce and evaluate ready-to-eat breakfast product for diabetics from African yam bean (Sphenostylis sternocarpa), sorghum (Sorghum bicolor L.) and unripe plantain (Musa paradisiaca L.) flour blends. Flours were produced from sorghum, African yam bean and unripe plantain and blended in 100:0:0, 65:30:5, 60:30:10, 55:30:15, 50:30:20 and 45:30:25 ratio of sorghum: African yam bean: unripe plantain flour, respectively. Ready-to-eat breakfast products were produced from each blend by toasting at $150^{\circ} \mathrm{C}$ for $5 \mathrm{~min}$. The products hypoglycemic and hypolipidemic potentials and effects on hematological parameters were evaluated using rat study. The fasting blood glucose (fbg) of the rats were significantly $(\mathrm{p}<0.05)$ reduced after 3 weeks of treatment from 200 to $81.63 \mathrm{mg} / \mathrm{dl}$. Rats fed sample $\operatorname{SAUP}_{5}(45: 30: 25)$ had the lowest mean fbg value of $81.63 \mathrm{mg} / \mathrm{ml}$. The cholesterol level of rats fed sample SAUP ${ }_{5}(945: 30: 25)$ was reduced from 3.56 to $2.10 \mathrm{mg} / \mathrm{dl}$, low density lipoprotein from 2.03 to $1.10 \mathrm{mg} / \mathrm{dl}$, triglycerides from 1.03 to $0.63 \mathrm{mg} / \mathrm{dl}$ and high density lipoprotein was increased from 0.47 to 0.97 $\mathrm{mg} / \mathrm{dl}$. Liver function of rats fed sample $\mathrm{SAUP}_{4}$ (50:30:20) was reduced from 100 to $23 \mathrm{mg} / \mathrm{dl}$, for Aspartate aminotransferase (AST), 49 to $23 \mathrm{mg} / \mathrm{dl}$ for alanine aminotransferase (ALT), and 33 to $19 \mathrm{mg} / \mathrm{dl}$ for alkaline phosphatase (ALP), respectively. Conclusion: The formulated ready-to-eat breakfast product was adequate for diabetic patients.
\end{abstract}

Keywords: African yam bean, Bioassay, Hypoglycemic, Hypolipidemic potentials, Ready-to-eat breakfast, Sorghum, Unripe plantain

Cite This Article: Onuh F. A., Mbaeyi-Nwaoha I. E., and Ani J.C., "Evaluation of the Hypoglycemic Potentials and Glycemic Index of Ready-to-eat Breakfast Products Using Animal Bioassay." American Journal of Food Science and Technology, vol. 7, no. 5 (2019): 161-168. doi: 10.12691/ajfst-7-5-5.

\section{Introduction}

Diabetes mellitus is a global health problem and it is on the increase in most part of the world. Though for many years, diabetes has been classified as the disease of affluence because management of the disease is associated with severe complications, which pose severe financial risks for families, member states, and the entire world [1]. However, in many part of sub-saharan Africa among the rural dwellers, there is a marked increase in the population of diabetics and other health problems related with food consumption. Due to these, there is an increased advocacy by world nutrition bodies such as the world health organization (WHO) on the consumption of functional foods. Also, a decrease in the consumption of sugars and foods that promote high glucose responses [2] should be advocated. It is therefore imperative to explore the potentials of lesser known plant, such as African yam bean and unripe plantain in the management of blood glucose among diabetics.

Breakfast cereals are produced by swelling, grinding, rolling or flaking of any cereal. There are two main classes of breakfast cereal, those requiring cooking, common in China, Japan and many African countries and the pre-cooked ready-to-eat cereals, common in Europe and North America [3]. Ready-to-eat breakfast cereals are gradually gaining acceptance in developing countries and replacing those that require cooking due to convenience, nutritional values, improved income and job demand among urban dwellers. Different processes used in the preparation of ready-to-eat cereal include flaking, puffing, shredding and granulation.

In developing countries particularly in sub-saharan Africa, breakfast meals for both adults and infants are made from local staples such as cereals, legumes, roots and tubers (cassava and potatoes) which are energy dense foods. Cereals are known to be deficient in lysine and tryptophan which are essentials for the maintenance of the 
health of both infants and adults [4]. Consequently, combining cereals with lysine and tryptophan rich legumes like African yam beans, pigeon pea among others in product formulation would complement the amino acid profile of the product. This has been found to be effective in reducing the incidence of malnutrition especially amongst children [5].

In many developing countries like Nigeria, health challenge like diabetes, characterized by hyperglycemia can also be managed through dietary diversification. Diet prepared to contain carbohydrates with low glycemic index has been proposed as a frontline management plan for diabetes. Foods with high glycemic index are those that are rapidly digested, absorbed and results in marked fluctuation in blood sugar, while low glycemic foods like African yam bean and plantain by virtue of their slow digestion and absorption produce gradual rise in blood sugar level [6]. Carbohydrates quality has therefore become a major issue to food processors because consumers are now selective on the type of carbohydrates to include in their diet. A current trend in nutrition is the consumption of low-carbohydrate diets, high dietary fibre foods, slowly digested food products, as well as increased intake of functional foods. Among the plant foods that meet up these requirement are plantain and African yam bean. Therefore, combining sorghum, African yam bean and unripe plantain to develop a breakfast product could contribute immensely in dietary management of diabetes in developing countries.

Nigeria accounted for $35 \%$ of African production of sorghum (Sorghum bicolor L.) in 2007 [7]. In 2013, the production statistic was 6,700.00 Metric tons and yield was 12.182 (hectogram/hectare) [8]. Sorghum is rich in some essential amino acids but low in lysine, but complimenting it with legumes like African yam bean, Bambara nut, groundnut, African yam bean, African breadfruit or pigeon pea will enhance its nutritional value Such supplementation has been widely used in production of weaning food (sorghum/pigeon-pea blends) [9], biscuits (from blends of millet/pigeon-pea) [10], and breakfast products (from sorghum/pigeon pea) [11].

African yam bean (Sphenostylis stenocarpa) is an important legume in Africa, a lesser - known legume of the tropical and sub - tropical areas of the world which has attracted research interest in recent times [12]. African yam bean is rich in protein and high in dietary fibre and these components are required for effective management of diabetes, hypertension and cardiovascular diseases due to its low glycemic index [4]. It produces nutritious pods, highly proteinous seeds and capable of growth in marginal areas where other pulses would not thrive. African yam bean grains contain 21 to $29 \%$ protein, is a good source of fibre, carbohydrates and is also rich in minerals [4]. It has also been reported to be of importance in the management of metabolic disorders like diabetes and hypertension because of its high dietary fibre content. It is eaten, roasted like groundnut or boiled and seasoned with ingredients such as oil, pepper, onions and salt. African yam beans though deficient in sulphur containing amino acid (methionine and cysteine), is high in lysine and so can be utilized as a complementary protein in foods to improve its nutritional quality and have been used in foods such as "Apula" to improve the micronutrient level [13].
Green plantain (Musa paradisiaca) is a potent source of vitamins $\mathrm{A}$ and $\mathrm{C}$, potassium and fibre. FAO [14] reported that over 2.3 million metric tons of plantains are produced in Nigeria annually. Unripe plantain though low in protein and fat, is rich in dietary fibre (8.82\%) and resistant starch (16.2\%) which helps to reduce blood sugar level [15]. Plantain has high carbohydrate content (31g/100g) and low fat content $(0.4 \mathrm{~g} / 100 \mathrm{~g})$. Plantain provides a better source of vitamin A than most other staples and contains low sodium in dietary terms and hence recommended for low sodium diets [16]. Oh et al. [17] noted that the high starch content (35\% on wet basis) of green plantain makes it ideal for plantain flour production. However, due to lack of storage facilities and inappropriate technologies for processing, about 35 to $60 \%$ post-harvest losses have been reported [18]. Considering the health benefits of unripe plantain and African yam bean composite blend in the preparation of breakfast product might not only impact nutritional benefits but also improve the health status of consumers of such product and consequently, increase their utilization. The major aim of this study was to produce and evaluate ready-to-eat breakfast product for diabetics from African yam bean (Sphenostylis sternocarpa), sorghum (Sorghum bicolor L.) and unripe plantain (Musa paradisiaca L.) flour blends.

\section{Materials and Method}

\subsection{Materials Procurement}

White sorghum grains (Sorghum bicolor L.), white African yam beans (Sphenostylis sternocarpa) and plantain (Musa parasidiaca L.) were purchased from Ogige main market, Nsukka Local Government area, Enugu state.

\subsection{Sample Preparation}

White variety of sorghum seeds, white variety of African yam bean and unripe plantain were cleaned and sorted to remove stones, dirt, chaff, and other extraneous matters before being used for further processing.

\subsubsection{Processing of Sorghum into Flour}

Five kilogram $(5 \mathrm{~kg})$ of the sorghum grains was prepared by the standard method [11]. The grains were sorted, washed and dried to a constant weight and milled in a hammer mill (Bentall superb model $200 \mathrm{~L} \mathrm{090),} \mathrm{to}$ obtained flour. The flour was sieved by passing through a $0.5 \mathrm{~mm}$ pore-sized sieve, stored in a high density polythelene bags until used for analysis.

\subsubsection{Processing of African Yam Bean Flour}

The procedure was used to process the African yam bean flour [4]. Five kilograms $(5 \mathrm{~kg})$ of cleaned white African yam beans was washed thoroughly with clean tap water and thereafter soaked for 12 hours and dehulled. The beans was dried in a hot air oven $\left(60 \pm 2^{\circ} \mathrm{C}\right.$ for $\left.10 \mathrm{~h}\right)$, and milled using an attrition mill. The flour obtained was sieved using $0.5 \mathrm{~mm}$ mesh sieve, packaged in high density polyethylene bags and stored until used. 


\subsubsection{Preparation of Plantain Flour}

The method was used to prepare the plantain flour [4]. Mature unripe plantain fruits were washed to remove adhering soil particles, peeled, sliced into thin slices of about $2 \mathrm{~mm}$ thickness, steam blanched (10 seconds at $80^{\circ} \mathrm{C}$ ) and dried (Gallenkamp S/No 90/20/190, U.K) at $50 \pm 5^{\circ} \mathrm{C}$ for $24 \mathrm{~h}$. The dried plantain slices were milled into flour using a hammer mill (Bentall Superb, Model 200L 09) and sieved through $500 \mu \mathrm{m}$ sieve. The flour was then packaged in high density polyethylene bag for further use and analysis.

\subsection{Product Formulation}

Composite flour was produced by blending sorghum, African yam bean flour and unripe plantain flour in different ratios as shown below in Table 1. The blends were mixed, conditioned and steamed for 10 minutes. The steamed product was allowed to age at $4^{\circ} \mathrm{C}$ for 24 hours, sliced by using knife to a flat thin size, and toasted in an oven at $150 \pm 2^{\circ} \mathrm{C}$ for 5 minutes, cooled and packaged in high density polythene bag to maintain crispiness and designated as product breakfast cereals [4] as shown in Figure 1.

Table 1. Composition of flour blends

\begin{tabular}{lccc}
\hline Sample & Sorghum (\%) & AYB (\%) & Unripe plantain (\%) \\
\hline $\mathrm{S}_{0}$ & 100 & 0 & 0 \\
$\mathrm{SAUP}_{1}$ & 65 & 30 & 5 \\
$\mathrm{SAUP}_{2}$ & 60 & 30 & 10 \\
$\mathrm{SAUP}_{3}$ & 55 & 30 & 15 \\
$\mathrm{SAUP}_{4}$ & 50 & 30 & 20 \\
SAUP $_{5}$ & 45 & 30 & 25 \\
\hline
\end{tabular}

$\mathrm{S}=$ Sorghum; $\mathrm{A}=$ African yam bean; $\mathrm{UP}=$ unripe Plantain flour blend.

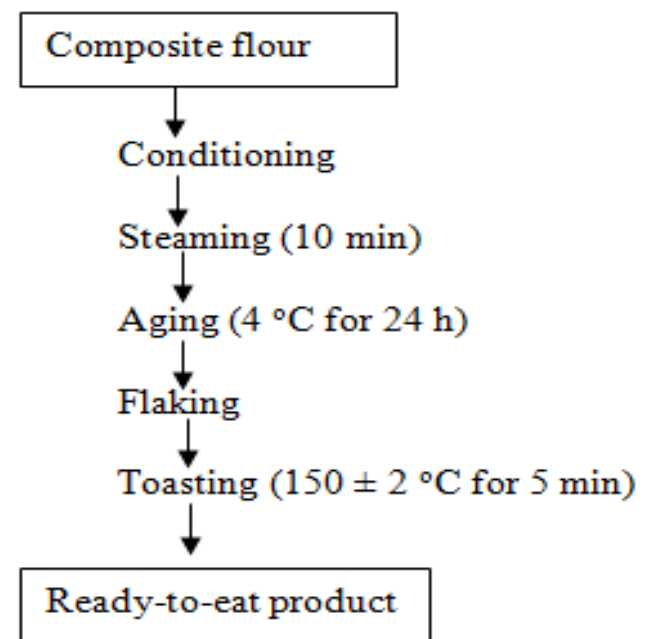

Figure 1. Flow diagram for the processing of breakfast product from blends of sorghum, African yam bean and unripe plantain [4]

\subsection{Bioassay Experiment}

The bioassay was carried out using sixty three (63) male albino rats of three months old, weighing $100-120 \mathrm{~g}$. The rats were induced with diabetes by injecting them with $1 \%$ solution of Alloxan injection $(120 \mathrm{mg} / \mathrm{kg}$ body weight) intraperitoneally (IP). Diabetic state was confirmed after two days and only rats with glucose concentration above $200 \mathrm{mg} / \mathrm{dl}$ were considered diabetic. The rats were divided into eight groups (seven per group) and fed the diets as shown in Table 2. The study was done for three weeks excluding seven days of acclimatization. The animals were fasted overnight before withdrawal of the blood samples for analysis.

\subsubsection{Body Weight Measurement}

Body weight of the rats was measured using the kitchen balance every seven days. Weight gain was determine as difference between the initial body weight and final body weight.

\subsubsection{Determination of Blood Glucose}

The glucometer and acucheck test strip (Life scan. Inc. Johnson-Johnson Company, multiplier California, and USA) were used and operated as described in the operation manual attached to it. A drop of the blood (0.04 $\mathrm{ml}$ ) was placed on the strip connected to the glucometer. The glucometer automatically displays concentration of the blood glucose.

\section{Determination of lipid profile}

Total cholesterol was determined by the method [19] using the Randox assay kit. The cholesterol esters in the serum were hydrolysed by cholesterol esterase into cholesterol and fatty acids. The cholesterol was oxidized using cholesterol oxidase to form cholestanone and hydrogen peroxide. The hydrogen peroxide was later hydrolysed by peroxidase to form water and Oxygen. The oxygen then reacts with 4-aminoantipyrene which is the chromogen to form quinoneimine. The samples were mixed and incubated for $10 \mathrm{~min}$ in a water bath at $37^{\circ} \mathrm{C}$. The colour produced was read colorimetrically at $540 \mathrm{~nm}$. Serum total cholesterol (TC) concentration was calculated thus:

\section{Total cholesterol $=\frac{\text { absorbance of sample }}{\text { absorbance of standard }} \times$ concentration of standard .}

\subsubsection{Determination of Low Density Lipoprotein (LDL)}

The quantitative determination of LDL was carried out using Randox assay kit. The LDL was determined as the difference between total cholesterol and the cholesterol content of the supernatant after precipitation of LDL fraction by polyvinyl sulphate (PVS) in the presence of polyethyleneglycol monomethylether. The LDL was calculated thus:

Total cholesterol $=1.5 \times$ supernatant cholesterol $(\mathrm{mmol})$.

Table 2. Diets fed experimental animals

\begin{tabular}{ll}
\hline Group & Diet \\
\hline Normal control & Normal rat chow \\
Diabetic control & Normal rat chow \\
SAUP $_{1}$ & 65:30:5 (Sorghum:African yam bean:unripe plantain) \\
SAUP $_{2}$ & $60: 30: 10$ (Sorghum:African yam bean:unripe plantain) \\
SAUP $_{3}$ & 55:30:15 (Sorghum:African yam bean:unripe plantain) \\
SAUP $_{4}$ & 50:30:20 (Sorghum:African yam bean:unripe plantain) \\
SAUP $_{5}$ & $45: 30: 25$ (Sorghum:African yam bean:unripe plantain) \\
SORG & Unblended Sorghum \\
\hline
\end{tabular}




\subsubsection{Determination of High Density Lipoprotein (HDL)}

The quantitative determination of LDL was carried out using Randox assay kit. Determination was by precipitating LDL from the serum by action of the polysaccharide in the presence of divalent cation. The high density lipoprotein cholesterol (HDL) present in the supernatant was determined spectrophotometrically at $500 \mathrm{~nm}$.

$$
H D L=180 \times \text { absorbance of supernatant }
$$

\subsubsection{Determination of Triglycerides (TG)}

The quantitative determination of triglyceride of the blood serum was done using Randox assay kit. The triglyceride was measured after enzymatic hydrolysis with lipase. The intensity of indicator (quinonemine), which was formed from hydrogen peroxide, 4-aminophenazone and 4- chlorophenol under catalytic influence of peroxidase, was determined spectrophotometrically (Jenway, JY/6705AP USA) at $500 \mathrm{~nm}$. The concentration of triglyceride was calculated thus:

$$
\begin{aligned}
& \text { Triglycerides concentration } \\
& =\frac{\text { absorbance of sample }}{\text { absorbance of standard }} \\
& \times \text { concentration of standard }(\mathrm{mmol}) \text {. }
\end{aligned}
$$

\subsection{Liver Function}

\subsubsection{Aspartate Aminotransferases (AST)}

The determination of in-vitro quantitative aspartate aminotransferases (AST) in serum was measured using Randox aspartate aminotransferases kits (Randox laboratories limited UK). A $0.1 \mathrm{ml}$ volume of blood serum was mixed with $1 \mathrm{ml}$ of substrate and incubated at $37{ }^{\circ} \mathrm{C}$ for $60 \mathrm{~min}$. The mixture was added to $1 \mathrm{ml}$ of $1,4-$ Dinitrophenol hydrazine (chromogen) and allowed to stand for $20 \mathrm{~min}$. After standing for $20 \mathrm{~min}, 5 \mathrm{mls}$ of $0.4 \mathrm{~N}$ $\mathrm{NaOH}$ was added and the solution was allowed to stand for $5 \mathrm{~min}$ before absorbance was taken at $540 \mathrm{~nm}$ against the standard blank.

\subsubsection{Determination of Alanine Aminotransferases} (ALT)

The determination of in-vitro quantitatitive alanine aminotransferases (ALT) in serum was measured by monitoring the concentration of pyruvate produced by transmination reaction between L- alanine and ketoglutarate hydrazine formed with 2, 4-dinitrophenylhydrazine using randox alanine aminotransferases assay kit. The absorbance was read at $546 \mathrm{~nm}$ and ALT activity was calculated with the following expression

$$
\text { ALT activity }=\frac{\mathrm{B} \times \text { sample dilution factor }}{\text { Time } \mathrm{x} \text { Sample volume }}
$$

Where $\mathrm{B}=$ amount of pyruvate generated.

\subsubsection{Determination of Alkaline Phosphatase (ALP)}

The determination of in-vitro quantitative alkaline phosphatase (ALP) in the serum was measured by colorimetric method using Randox alkaline phosphatase assay kit. The P-nitrophynylphosphate was hydrolysed in the presence of ALP to form phosphate and P-nitrophenol. Colorimetric method was used to estimate the concentration of ALP after calibrating with water and absorbance was read at $405 \mathrm{~nm}$ after $3 \mathrm{~min}$. The concentration of ALP was calculated with the expression

$$
A L P=2760 \times 405(\mathrm{~nm} / \mathrm{min}) U / L .
$$

\subsection{Experimental Design and Data Analysis}

The results were laid out in completely randomized design. Data were subjected to one way analysis of variance (ANOVA) using the statistical package for social sciences (SPSS) and means were separated using Duncan's new multiple range test. Differences between means were accepted at $\mathrm{p}<0.05$ [20].

\section{Results and Discussion}

\subsection{Effect of the Breakfast Products on Weight Gain of the Rats}

Table 3 shows the mean weight of the experimental rats fed the formulated breakfast product. The weight of the animals ranged from $84-109 \mathrm{~g}$ across the group. There were significant $(p<0.05)$ difference in the body weight of the rats fed the formulated diet. A significant $(\mathrm{p}<0.05)$ decrease in the body weight of the rats was observed after induction with alloxan.

The entire group showed reduction in weight in the second week and subsequent increase on the third and fourth weeks. The reduction could be attributed to reduced feed intake since the animals were diabetic and therefore suffered from degradation of muscle and structural proteins which are typical of diabetic symptoms. The loss in body weight of the diabetic animals agreed with the findings of other researchers [21] who observed similar effect on diabetic animals induced with streptozotocin. This reduction could also be linked to degradation of structural proteins and muscle wasting.

There were decreased body weights of the rats fed the SORG formulation, because the group (SORG) was not able to recover in weight until the end of the experiment, while groups (SAUP) fed the formulated diet had 3\% - 5\% increase in body weight.

The overall increase in body weight of rats fed the formulated diet could be attributed to the composition of the products made up of carbohydrates and protein, and that the product did not induce anorexia (loss of appetite), an effect that could have resulted to loss of body weight. The result obtained from this study is in contrast with the result reported by Okogu [22], where there was loss in weight of the rats after being fed with a cereal legume breakfast from hungry rice, maize and African yam bean.

\subsection{Effect of the Breakfast Products on Blood Glucose of the Rats}

Table 4 shows the result of the fasting blood glucose of the rats. The fasting blood glucose level of the rats before 
induction ranged from 111 to $148 \mathrm{mg} / \mathrm{ml}$. After alloxan induction the fasting blood sugar of diabetic rats ranged from $85 \mathrm{mg} / \mathrm{ml}$ to $254 \mathrm{mg} / \mathrm{ml}$. There was a significant $(\mathrm{p}<$ $0.05)$ increase in the fasting blood glucose of all the rat groups induced with alloxan. After 21 days of feeding, the fasting blood glucose reduced significantly $(p<0.05)$ in the diabetic treated groups while the blood glucose increased significantly in the diabetic control group till the end of the study, and significant $(\mathrm{p}<0.05)$ decrease in the blood glucose level of rats fed the formulated diet was observed across each week.

Feeding the diabetic fed group with the formulated (SAUP) diet reduced the fasting blood glucose, indicating that the diets exhibited hypoglycemic effect, by promoting regeneration of the cells and protection of the cells from destruction by restricting glucose overload, thereby confirming the report that plantain and African yam bean had the potential of reducing blood glucose. The measurement of blood glucose is the most important biological marker in the diagnosis and monitoring of diabetes mellitus, both in clinical and experimental settings [23]. Alloxan causes diabetes, through its ability to destroy the insulin producing beta cells of the pancreas [24].

\subsection{Effect of the Breakfast Products on the Lipid Profile of the Rats}

Table 5 shows the effect of the intake of the formulated breakfast products on serum lipid profile of the albino diabetic rats. The cholesterol (CHOL) level for samples ranged from 2.20 to $3.56 \mathrm{mmol} / \mathrm{L}$, triaglycerol (TAG) ranged from 0.60 to $1.03 \mathrm{mmol} / \mathrm{L}$. and low density lipoprotein (LDL) level ranged from 1.03 to $2.03 \mathrm{mmol} / \mathrm{L}$.

There were significant $(\mathrm{p}<0.05)$ reductions in the serum cholesterol, tryglycerol and increased HDL in the diabetic treated group than in the diabetic control group. Sample $\mathrm{SAUP}_{4}$ had more effect on the cholesterol level of the diabetic rat. The decrease in the CHOL value in the rats shows that the diet had positive impact on the lipid metabolism of the diabetic rats [25]. The result agreed with the report of other researchers who reported that plantain and African yam bean have the potentials of combating dyslipidemia which is one of the complications of diabetes [26].

In diabetic condition, increase in blood glucose is usually accompanied by an increase in plasma cholesterol, triaglycerol, LDL. Rats fed the formulated diet showed increase in HDL while there was a decrease in HDL in the control group. The decreased HDL may be due to destructive breakdown of protein and amino acids that were released and used for glycogenesis. It was observed that HDL has a protective effect against cardiovascular diseases as it removes excess cholesterol from circulation and carries it back to the liver where it is degraded and eliminated out of the body [27].

\subsection{Effect of the Breakfast Products on Liver Function of the RATS}

Table 6 shows the effect of the formulated breakfast products on the liver function of the alloxan diabetic rats. The alanine aminotransferases (ALT), alkaline phosphatase (ALP), and aspartase aminotransferases (AST) of the rats fed the breakfast product ranged from 15 to $49 \mathrm{u} / 1,69.66$ to $100.67 \mathrm{u} / 1$ and 19.17 to $33.33 \mathrm{u} / \mathrm{l}$, respectively.

Table 3. Effect of the breakfast products on weight gain of the rats (grams)

\begin{tabular}{llll}
\hline Group & Week 1 & Week 2 & Week 3 \\
\hline Normal control & $104.00^{\mathrm{c}} \pm 1.00$ & $107.00^{\mathrm{a}} \pm 1.53$ & $108.00^{\mathrm{a}} \pm 1.00$ \\
Diabetic control & $108.00^{\mathrm{a}} \pm 1.00$ & $104.00^{\mathrm{b}} \pm 1.00$ & $99.00^{\mathrm{b}} \pm 1.00$ \\
SAUP $_{1}$ & $103.00^{\mathrm{c}} \pm 1.00$ & $100.00^{\mathrm{c}} \pm 1.00$ & $104.00^{\mathrm{ab}} \pm 1.00$ \\
SAUP $_{2}$ & $104.00^{\mathrm{c}} \pm 1.00$ & $100.00^{\mathrm{c}} \pm 1.00$ & $105.00^{\mathrm{ab}} \pm 1.00$ \\
SAUP $_{3}$ & $106.00^{\mathrm{b}} \pm 1.00$ & $103.00^{\mathrm{b}} \pm 1.00$ & $106.00^{\mathrm{ab}} \pm 1.00$ \\
SAUP $_{4}$ & $108.00^{\mathrm{a}} \pm 1.00$ & $103.00^{\mathrm{b}} \pm 1.00$ & $104.00^{\mathrm{ab}} \pm 1.00$ \\
SAUP $_{5}$ & $101.00^{\mathrm{d}} \pm 1.00$ & $97.67^{\mathrm{d}} \pm 1.00$ & 1.00 \\
SORG $^{\mathrm{a}}$ & $97.00^{\mathrm{e}} \pm 1.00$ & $93.00^{\mathrm{e}} \pm 1.00$ & $106.00^{\mathrm{ab}} \pm 1.00$ \\
\hline
\end{tabular}

Values are means of triplicate determinations \pm SD. Means within a column with same superscripts are not significantly ( $\mathrm{p}>0.05)$ different Key: $\mathrm{SORG}=100 \%$ Sorghum; $\mathrm{SAUP}_{1}=65: 30: 5$; Sorghum:African yam bean:unripe plantain blend; SAUP $2=60: 30: 10 ;$ Sorghum:African yam bean:unripe plantain blend; $\mathrm{SAUP}_{3}=55: 30: 15$; Sorghum:African yam bean:unripe plantain blend; SAUP $=50: 30: 20$; Sorghum:African yam bean:unripe plantain blend; SAUP $_{5}=45: 30: 25$; Sorghum:African yam bean:unripe plantain blend

Table 4. Effect of the breakfast products on blood glucose of the rats $(\mathrm{mg} / \mathrm{ml})$

\begin{tabular}{|c|c|c|c|c|c|}
\hline GROUP & Before induction & After induction & Week one & Week two & Week three \\
\hline Normal control & $111.33^{\mathrm{g}} \pm 0.58$ & $111.0^{\mathrm{g}} \pm 1.00$ & $113.00^{\mathrm{f}} \pm 1.00$ & $111.00^{\mathrm{f}} \pm 1.53$ & $107.0^{\mathrm{c}} \pm 1.00$ \\
\hline Diabetic control & $131.67^{\mathrm{d}} \pm 0.58$ & $216.00^{\mathrm{e}} \pm 1.00$ & $244.00^{\mathrm{a}} \pm 1.00$ & $250.00^{\mathrm{g}} \pm 1.00$ & $254.00^{\mathrm{a}} \pm 1.00$ \\
\hline SAUP $_{1}$ & $132.67^{b} \pm 0.58$ & $241.00^{\mathrm{b}} \pm 1.00$ & $192.00^{\mathrm{c}} \pm 1.00$ & $191.00^{\mathrm{c}} \pm 1.00$ & $95.00^{\mathrm{d}} \pm 1.00$ \\
\hline $\mathrm{SAUP}_{2}$ & $148.00^{\mathrm{a}} \pm 0.58$ & $232.00^{\mathrm{d}} \pm 1.00$ & $100.00^{\mathrm{d}} \pm 1.00$ & $95.67^{\mathrm{c}} \pm 21.22$ & $91.00^{\mathrm{e}} \pm 1.00$ \\
\hline $\mathrm{SAUP}_{3}$ & $138.00^{\mathrm{b}} \pm 0.58$ & $234.00^{\mathrm{c}} \pm 1.00$ & $114.00^{\mathrm{f}} \pm 1.00$ & $97.00^{\mathrm{g}} \pm 26.76$ & $94.67^{\mathrm{d}} \pm 1.00$ \\
\hline $\mathrm{SAUP}_{4}$ & $133.00^{c} \pm 0.58$ & $241.00^{c} \pm 1.00$ & $182.00^{\mathrm{d}} \pm 1.00$ & $135.00^{\mathrm{d}} \pm 28.04$ & $85.67^{\mathrm{e}} \pm 1.00$ \\
\hline $\mathrm{SAUP}_{5}$ & $121.00^{\mathrm{f}} \pm 0.58$ & $207.00^{f} \pm 1.00$ & $149.00^{\mathrm{e}} \pm 1.00$ & $117.00^{\mathrm{e}} \pm 29.09$ & $81.63^{\mathrm{f}} \pm 1.00$ \\
\hline SORG & $126.30^{\mathrm{e}} \pm 0.58$ & $256.00^{\mathrm{a}} \pm 1.00$ & $220.00^{\mathrm{b}} \pm 1.00$ & $224.00^{\mathrm{b}} \pm 23.989$ & $229.00^{\mathrm{b}} \pm 0.00$ \\
\hline
\end{tabular}

Values are means of triplicate determinations \pm SD. Means within a column with same superscripts are not significantly ( $\mathrm{p}>0.05$ ) different Key: $\mathrm{SORG}=100 \%$ Sorghum; $\mathrm{SAUP}_{1}=65: 30: 5$; Sorghum:African yam bean:unripe plantain blend; SAUP ${ }_{2}=60: 30: 10$; Sorghum:African yam bean:unripe plantain blend; $\mathrm{SAUP}_{3}=55: 30: 15$; Sorghum:African yam bean:unripe plantain blend; SAUP ${ }_{4}=50: 30: 20$; Sorghum:African yam bean:unripe plantain blend; $\mathrm{SAUP}_{5}=45: 30: 25$; Sorghum:African yam bean:unripe plantain blend 
Table 5. Effect of the breakfast products on the lipid profile of the rats

\begin{tabular}{ccccc}
\hline GROUP & CHOL $(\mathrm{mmol})$ & TAG $(\mathrm{mmol})$ & HDL $(\mathrm{mmol})$ & LDL $(\mathrm{mmol})$ \\
\hline Normal control & $2.80^{\mathrm{b}} \pm 0.17$ & $0.60^{\mathrm{c}} \pm 0.10$ & $0.67^{\mathrm{cd}} \pm 0.12$ & $1.60^{\mathrm{ab}} \pm 0.10$ \\
Diabetic control $^{\mathrm{a}}$ & $3.56^{\mathrm{a}} \pm 0.13$ & $1.03^{\mathrm{a}} \pm 0.15$ & $0.47^{\mathrm{d}} \pm 0.12$ & $2.03^{\mathrm{a}} \pm 0.25$ \\
SAUP $_{1}$ & $2.63^{\mathrm{b}} \pm 0.42$ & $0.77^{\mathrm{bcd}} \pm 0.58$ & $0.57^{\mathrm{cd}} \pm 0.15$ & $1.13^{\mathrm{c}} \pm 0.12$ \\
SAUP $_{2}$ & $2.60^{\mathrm{b}} \pm 0.44$ & $0.70^{\mathrm{bcd}} \pm 0.10$ & $0.60^{\mathrm{cd}} \pm 0.10$ & $1.23^{\mathrm{bc}} \pm 0.21$ \\
SAUP $_{3}$ & $2.50^{\mathrm{c}} \pm 0.10$ & $0.70^{\mathrm{bcd}} \pm 0.10$ & $0.77^{\mathrm{bc}} \pm 0.21$ & $1.03^{\mathrm{c}} \pm 0.15$ \\
SAUP $_{4}$ & $2.10^{\mathrm{d}} \pm 2.52$ & $0.87^{\mathrm{ab}} \pm 0.58$ & $0.97^{\mathrm{ab}} \pm 0.06$ & $1.10^{\mathrm{c}} \pm 0.10$ \\
SAUP $_{5}$ & $2.20^{\mathrm{d}} \pm 0.10$ & $0.63^{\mathrm{cd}} \pm 0.58$ & $1.20^{\mathrm{a}} \pm 0.20$ & $1.13^{\mathrm{c}} \pm 0.15$ \\
SORG $^{\text {SOR }}$ & $3.00^{\mathrm{a}} \pm 0.46$ & $0.83^{\mathrm{abc}} \pm 0.16$ & $0.50^{\mathrm{d}} \pm 0.10$ & $1.67^{\mathrm{ab}} \pm 0.57$ \\
\hline
\end{tabular}

Values are means of triplicate determinations \pm SD. Means within a column with same superscripts are not significantly ( $\mathrm{p}>0.05)$ different

Key: $\mathrm{SORG}=100 \%$ Sorghum; $\mathrm{SAUP}_{1}=65: 30: 5$; Sorghum:African yam bean:unripe plantain blend; SAUP $2=60: 30: 10 ;$ Sorghum:African yam bean:unripe plantain blend; SAUP $_{3}=55: 30: 15$; Sorghum:African yam bean:unripe plantain blend; SAUP $=50: 30: 20$; Sorghum:African yam bean:unripe plantain blend; $\mathrm{SAUP}_{5}=45: 30: 25$; Sorghum:African yam bean:unripe plantain blend

The diabetic control group had significantly $(p<0.05)$ high value of $49.00 \mathrm{u} / 1,100 \mathrm{u} / 1$, and $33 \mathrm{u} / 1$ of AST, ALP, and ALT values, respectively when compared to the normal control and groups fed the formulated products. Sample SAUP 4 showed consistent decrease in AST, ALP and ALT level of the rats followed by $\mathrm{SAUP}_{5}$, while there was marked decrease in AST, ALP and ALT in the other formulations as the proportion of plantain flour increased.

An increased AST, ALT and ALP in the serum are indication of hepatocellular damage since ALT is an enzyme that helps metabolize protein but when the liver is damaged, the enzymes are released into the bloodstream, and presence of ASP in the blood stream also signifies a damaged liver [28]. Therefore a decreased AST, ALT and ALP indicates that the breakfast products tend to prevent liver damage by maintaining the integrity of the plasma membrane, thereby suppressing leakage of the enzymes through the membrane, exhibiting hepato protective activity in alloxan induced diabetic rats.

\subsection{Effect of the breakfast products on kidney function of the rats}

Table 7 shows the effect of the formulated breakfast products on the kidney function of the rats. The urea level of the rats ranged from 18.67 to $64.00 \mathrm{mg} / \mathrm{dl}$, while the creatinine level ranged from $1.033 \mathrm{mg} / \mathrm{dl}$ to $2.03 \mathrm{mg} / \mathrm{dl}$.

The diabetic control group had higher creatinine $(2.04 \mathrm{mg} / \mathrm{dl})$ and urea $(64.00 \mathrm{mg} / \mathrm{dl})$ values than groups fed the formulated diet. The high urea and creatinine level observed in diabetic control could probably be due to diminished ability of the kidney to filter urea and creatinine from the body. This elevation could be attributed to the release of these enzymes from the cytoplasm into blood circulation after rupture of the plasma membrane and cellular damage [29]. However, significant $(p<0.05)$ decreases were observed in the serum creatinine and urea levels of the diabetic rats fed with $\mathrm{SAUP}_{3}$ and $\mathrm{SAUP}_{4}$.

\subsection{Effect of the Breakfast Products on Hematological Indices of the Rats}

Table 8 shows the hematological indices of the rats fed the formulated breakfast products from sorghum, African yam bean and unripe plantain blend. The packed cell volume of the rats ranged from 36.67 to $45.00 \%$, the hemoglobin content of the rats ranged from 11.97 to $15.67 \mathrm{~g} / \mathrm{dl}$, red blood cell count ranged from $26.00 \times 10^{9}$ to $39.67 \times 10^{9} / 1$ and the white blood cell count of the rats ranged from $7.80 \times 10^{3}$ to $10.00 \times 10^{3} \mathrm{~mm}^{-3}$.

The diabetic control group had a lower PCV level, HB, $\mathrm{RBC}$ and higher WBC value compared to the normal control and those of the formulated product. A low RBC count is an indication that the body is anemic and therefore more antibodies were needed to be able to respond to the anemic condition thereby resulting in a high WBC.

The increased level of WBC in diabetic control group indicates suppression of the immune system suggesting that the diet (rat chow) could not cause any change in boosting the immune system of the control group [30]. The breakfast products were able to increase to an appreciable level the RBC and $\mathrm{WBC}$ of the rats suggesting a boost in the immune system probably due to the composition of the diet.

Table 6. Effect of the formulated breakfast products on liver function of the rats

\begin{tabular}{cccc}
\hline GROUP & ALT $(\mathrm{u} / \mathrm{l})$ & AST $(\mathrm{u} / \mathrm{l})$ & ALP $(\mathrm{u} / \mathrm{l})$ \\
\hline Normal control & $38.67^{\mathrm{b}} \pm 2.31$ & $69.67^{\mathrm{c}} \pm 1.53$ & $24.67^{\mathrm{ab}} \pm 0.58$ \\
Diabetic control & $49.00^{\mathrm{a}} \pm 3.61$ & $100.67^{\mathrm{a}} \pm 5.20$ & $33.33^{\mathrm{a}} \pm 2.08$ \\
SAUP $_{1}$ & $35.33^{\mathrm{b}} \pm 1.15$ & $74.67^{\mathrm{c}} \pm 5.59$ & $27.67^{\mathrm{ab}} \pm 2.89$ \\
SAUP $_{2}$ & $32.33^{\mathrm{cd}} \pm 4.04$ & $75.33^{\mathrm{c}} \pm 7.51$ & $22.33^{\mathrm{a}} \pm 1.15$ \\
SAUP $_{3}$ & $36.33^{\mathrm{b}} \pm 3.51$ & $76.00^{\mathrm{c}} \pm 3.61$ & $25.33^{\mathrm{ab}} \pm 2.52$ \\
SAUP $_{4}$ & $23.33^{\mathrm{e}} \pm 2.89$ & $70.33^{\mathrm{c}} \pm 4.04$ & $19.17^{\mathrm{b}} \pm 14.44$ \\
SAUP $_{5}$ & $31.67^{\mathrm{d}} \pm 2.89$ & $72.33^{\mathrm{c}} \pm 10.26$ & $28.67^{\mathrm{ab}} \pm 4.16$ \\
SORG $^{\mathrm{a}}$ & $37.67^{\mathrm{bc}} \pm 2.31$ & $93.33^{\mathrm{b}} \pm 15.28$ & $29.33^{\mathrm{ab}} \pm 0.58$ \\
\hline
\end{tabular}

Values are means of triplicate determinations \pm SD. Means within a column with same superscripts are not significantly ( $\mathrm{p}>0.05$ ) different

Key: $\mathrm{SORG}=100 \%$ Sorghum; SAUP $1=65: 30: 5$; Sorghum:African yam bean:unripe plantain blend; SAUP $2=60: 30: 10$; Sorghum:African yam bean:unripe plantain blend; SAUP $_{3}=55: 30: 15$; Sorghum:African yam bean:unripe plantain blend; SAUP $=50: 30: 20$; Sorghum:African yam bean:unripe plantain blend; $\mathrm{SAUP}_{5}=45: 30: 25$; Sorghum:African yam bean:unripe plantain blend; ALT= Alanine aminotransferases, ALP $=$ Alkaline phosphatase, and AST = Aspartase aminotransferases 
Table 7. Effect of the breakfast products on kidney function of the rats

\begin{tabular}{lll}
\hline GROUP & Urea $(\mathrm{mg} / \mathrm{dl})$ & Creatinine $(\mathrm{mg} / \mathrm{dl})$ \\
\hline Normal control & $18.67^{\mathrm{d}} \pm 13.80$ & $1.03^{\mathrm{e}} \pm 0.16$ \\
Diabetic control & $64.00^{\mathrm{a}} \pm 7.55$ & $2.04^{\mathrm{b}} \pm 0.32$ \\
SAUP $_{1}$ & $45.00^{\mathrm{bc}} \pm 1.53$ & $1.62^{\mathrm{bcd}} \pm 0.02$ \\
$\mathrm{SAUP}_{2}$ & $42.00^{\mathrm{bc}} \pm 3.00$ & $1.60^{\mathrm{bcd}} \pm 0.10$ \\
$\mathrm{SAUP}_{3}$ & $39.33^{\mathrm{bc}} \pm 3.51$ & $1.41^{\mathrm{d}} \pm 0.11$ \\
SAUP $_{4}$ & $36.67^{\mathrm{c}} \pm 2.08$ & $1.49^{\mathrm{cd}} \pm 0.07$ \\
SAUP $_{5}$ & $48.33^{\mathrm{b}} \pm 2.52$ & $1.79^{\mathrm{bc}} \pm 0.12$ \\
SORG & $50.00^{\mathrm{b}} \pm 1.00$ & $1.92^{\mathrm{ab}} \pm 0.38$ \\
\hline
\end{tabular}

Values are means of triplicate determinations $\pm \mathrm{SD}$. Means within a column with same superscripts are not significantly (p>0.05) different

Key: $\mathrm{SORG}=100 \%$ Sorghum; $\mathrm{SAUP}_{1}=65: 30: 5$; Sorghum:African yam bean:unripe plantain blend; $\mathrm{SAUP}_{2}=60: 30: 10$; Sorghum:African yam bean:unripe plantain blend; $\mathrm{SAUP}_{3}=$ 55:30:15; Sorghum:African yam bean:unripe plantain blend; $\mathrm{SAUP}_{4}=50: 30: 20$; Sorghum:African yam bean:unripe plantain blend; $\mathrm{SAUP}_{5}=45: 30: 25$; Sorghum:African yam bean:unripe plantain blend.

Table 8. Effect of the breakfast products on hematological indices of the rats

\begin{tabular}{|c|c|c|c|c|}
\hline GROUP & PCV (\%) & HB (\%) & $\operatorname{RBC}\left(10^{9} / 1\right)$ & WBC $\left(10^{4} / \mathrm{mm}^{-3}\right)$ \\
\hline Normal control & $44.67^{\mathrm{a}} \pm 4.16$ & $15.37^{\mathrm{ab}} \pm 1.10$ & $36.67^{\mathrm{ab}} \pm 4.16$ & $5.93^{\mathrm{a}} \pm 305.31$ \\
\hline Diabetic control & $36.67^{b} \pm 2.31$ & $15.17^{\mathrm{ab}} \pm 1.11$ & $26.00^{\mathrm{d}} \pm 2.00$ & $10.03^{c} \pm 346.41$ \\
\hline $\mathrm{SAUP}_{1}$ & $39.67^{\mathrm{ab}} \pm 4.73$ & $14.57^{\mathrm{abc}} \pm 1.25$ & $30.00^{\mathrm{a}} \pm 1.16$ & $8.67^{\mathrm{bc}} \pm 808.29$ \\
\hline $\mathrm{SAUP}_{2}$ & $38.33^{\mathrm{ab}} \pm 3.51$ & $13.10^{\mathrm{abc}} \pm 0.87$ & $32.00^{\mathrm{ab}} \pm 2.00$ & $8.53^{\mathrm{bc}} \pm 832.67$ \\
\hline $\mathrm{SAUP}_{3}$ & $42.67^{\mathrm{ab}} \pm 2.31$ & $13.80^{\mathrm{abc}} \pm 1.56$ & $34.00^{\mathrm{abc}} \pm 2.00$ & $8.80^{\mathrm{bc}} \pm 346.41$ \\
\hline $\mathrm{SAUP}_{4}$ & $44.67^{\mathrm{a}} \pm 2.31$ & $12.60^{\mathrm{bc}} \pm 2.76$ & $32.33^{b c} \pm 7.23$ & $7 . .93^{\mathrm{abc}} \pm 130.00$ \\
\hline SORG & $42.67^{\mathrm{ab}} \pm 3.79$ & $15.67^{\mathrm{a}} \pm 0.58$ & $30.00^{\text {cd }} \pm 2.00$ & $9.03^{c} \pm 513.16$ \\
\hline
\end{tabular}

Values are means of triplicate determinations \pm SD. Means within a column with same superscripts are not significantly ( $p>0.05)$ different Key: $\mathrm{SORG}=100 \%$ Sorghum; $\mathrm{SAUP}_{1}=65: 30: 5$ Sorghum:African yam bean:unripe plantain blend; SAUP $2=60: 30: 10$; Sorghum: African yam bean:unripe plantain blend; $\mathrm{SAUP}_{3}=55: 30: 15$; Sorghum:African yam bean:unripe plantain blend; SAUP $=50: 30: 20$; Sorghum:African yam bean:unripe plantain blend; $\mathrm{SAUP}_{5}=45: 30: 25$; Sorghum:African yam bean:unripe plantain blend; $\mathrm{PCV}=$ packed cell volume; HB $=$ haemoglobin; $\mathrm{RBC}=$ Red blood cell; $\mathrm{WBC}=$ White blood cell

Ready to eat breakfast product was formulated from flour blends of sorghum, African yam bean and unripe plantain. Sample SAUP $_{5}(45: 30: 25)$ increased the white blood and red blood cell counts by $3 \%$ and $7 \%$, respectively. Sample SAUP $_{5}$ (containing 45:30:25 ratio of sorghum, African yam bean and unripe plantain), reduced the fasting blood glucose ( $\mathrm{fbg}$ ) level of the diabetic rats from $207.00 \mathrm{mg} / \mathrm{ml}$ to $81.00 \mathrm{mg} / \mathrm{ml}$ and had the lowest glycemic index (50\%), while SORG (control) had the highest glycemic index of $80 \%$.

\section{Conflicts of Interest}

All authors contributed equally and declare no conflict of interest.

\section{References}

[1] International Diabetes Federation (IDF)). Definition, diagnosis and classifications of diabetes mellitus. Available at http://www.idf.org/diabetesatlas/5e/diabetes, (2012).

[2] WHO/FAO. Diet, nutrition and the prevention of chronic diseases: Report of a joint WHO/FAO expert consultation, Geneva, January 28-February 1, 2002. WHO Technical Report Series 916, FAO/WHO, Geneva, Switzerland. pp. 1-149 (2003).

[3] Matz, S. A. Breakfast cereals. In: The chemistry and technology of cereals as food and feed. AVI Publ. CO., Westport, Connecticut, pp. 645-676, (1970).

[4] Enwere, N. J. Foods of Plant Origin. Afro-Orbis publication Ltd., Nsukka, Nigeria. pp. 30-34, 60, (1998).

[5] Ene-obong, H. N. and Obizoba, I. C. Protein quality of some Nigerian traditional diets based on African yam bean (Sphenostylis sternocarpa) and pigeon pea (Cajanus cajan). Plant Foods for Human Nutrition, 48: 297- 309, (1996).

[6] Health Focus International The health focus trend report: The national study of public attitudes and actions towards shopping and eating. Health Focus International, St. Petersburg. pp 18-19, (2005).

[7] UN/FAO (United Nation/ Food and Agriculture Organization). Trade database, Production database, (2012). http://faostat.fao.org.

[8] FAOSTAT. Sorghum production quantity for Nigeria, (2012). Available from http://www.factfish.com/statistic-country/Nigeria. Accessed on January 27, 2015.

[9] Maghoub, S. E. O. Production and evaluation of weaning foods based on sorghum and legumes. Plant Foods for Human Nutrition, 54: 29-42, (1999).

[10] Eneche, E. H. Biscuit-making potential of millet/pigeon-pea flour blends. Plant Foods for Human Nutrition, 54: 21-27, (1999).

[11] Mbaeyi, I. E. and Onweluzo, J. C. Effect of sprouting and pregelatinizaton on the nutritional quality of sorghum (Sorghum bicolor L.). Journal of Tropical Agriculture, Food, Environment and Extension, 9:184-192, (2010).

[12] Azeke, M. A., Fretzdorft, B., Buencing - Pfare, H., Holzapfel, W. and Betsche T. Nutritional value of African yam bean (Sphenostylis stenocarpa): Improvement by lactic acid fermentation. Journal of Food Science and Agriculture, 85(2): 963-970, (2005).

[13] Yusufu, P. A., Egwujeh, S. I. D., Damak, A. and Netala, J. Enrichment of 'Apula'-A roasted maize meal with African yam bean and plantain fruit flour.

[14] Food and Agricultural Organization. (FAO) Food and Agricultural Indicators. (2014). Available from http://www.fao.org

[15] Ayodele, O. H. and Erema, V. G. Glycemic indices of unripe plantain meals. African Journal of Food Science, 4: 514-521, (2011).

[16] USDA. National Nutrient Database for Standard Reference, (2009). Available from http://www.nal.usda.gov/fnic/foodcomp/plantain.

[17] Oh, N. H., Seib, P. A. and Chung, D. S. Noodles. III. Effects of processing variables on quality characteristics of dry noodles. Cereal Chemistry, 62: 437-440, (1985). 
[18] Abioye, V. F., Adeomowaye, G. O., Babarinde, O. and Adesigbin, M. K. Chemical, physicochemical and sensory properties of soy-plantain flour. African Journal of Food Science, 5: 176-180, (2011).

[19] Siedel, T., Ziegenhom, J., Hagele, E. O. and Wahlefed, A. Reagent for the determination of serum total cholesterol with improved lipolytic efficiency. Clinical Chemistry, 29: 1075-1080, (1983).

[20] Steele, R. G. and Torrie, J. H. Principles and Procedures of Statistics $\left(2^{\text {nd }}\right.$ Edition), McGraw-Hill, New York. pp. 623, (1980).

[21] Oyedemi, S. O, Yakubu, M. T., and Afolayan, A. J. Antidiabetic activities of aqueous leaves extract of Leonotis leonurus in streptozotocin induced diabetic rats. Journal of Medical Plant Resources, 5: 119-125, (2011).

[22] Okogu, N. R. Production and evaluation of breakfast cereal from blends of hungry rice, African yam bean and maize fibre for diabetics. An M.Sc Dissertation from the Department of Food science and Technology, University of Nigeria, Nsukka, (2012).

[23] Mayfield, J. Diagnosis and classification of Diabetes mellitus: New criteria. American Academic Family Physicians 58(6): 1355-1362, (1998).

[24] Lenzen, S. and Panten, U. Alloxan history and mechanism of action. Diabetology, 31: 337-342, (1988).
[25] Mitra, S. K., Gopumadhavan, S., Muralidhar, T. S., Anturlikar, S. D. and Sujatha, M. B. Effect of D-400, a herbomineral preparation on lipids profile, glycerated haemoglobin and glucose tolerance in streptozotocin induced diabetes in rats. Indian Journal of Experimental Biology, 33: 798-800, (1995).

[26] Eleazu, C. O., Okafor, P. N. and Ahamefuna I. Total antioxidant capacity, nutritional composition and inhibitory activity of unripe plantain (Musa paradisiacae) on oxidative stress in alloxan induced diabetic rabbits. Pakistan Journal of Nutrition, 9 (11): 1052-1057, (2010).

[27] Imafidon, K. E. Tissue lipid profile of rats administered aqueous extract of Hibiscus Rosa sinensis. Linn. Journal of Basic and Applied Sciences, 26 (1): 1-3, (2010).

[28] Owolabi, O. J., Amaechina, F. C. and Okoro, M. Effect of ethanol leaf extract of Newbouldia laevis on blood glucose levels of diabetic rats. Tropical Journal of Pharmaceutical Research, 10(3): 239-254, (2011).

[29] Nwanjo, H. U. Studies on the effect of aqueous extract of Phyllanthus niruri on plasma glucose level and some hepatospecific markers in diabetic Wistar rats. International Journal of Laboratory Medicine, 2: 1-18, (2007).

[30] Palacios, I., Lozano, M., Moro, C. Antioxidant properties of phenolic compound occurring in edible mushrooms. Food Chemistry, 128: 674-678, (2011).

(C) The Author(s) 2019. This article is an open access article distributed under the terms and conditions of the Creative Commons Attribution (CC BY) license (http://creativecommons.org/licenses/by/4.0/). 